\title{
Edukasi Protokol Kesehatan dalam Menjalankan New Normal di Sekolah Melalui Pendidikan Literasi Mitigasi Bencana Covid-19
}

\author{
${ }^{1}$ Syahrial A., ${ }^{2}$ Chairunisyah Sahidu, ${ }^{3}$ Joni Rokhmat, ${ }^{4}$ Muhammad Zuhdi, ${ }^{5}$ Muhammad \\ Taufik \\ 1,2,3,4,5 Prodi Pendidikan Fisika, PMIPA, Universitas Mataram, Jln. Majapahit 62 Mataram, \\ NTB \\ Email Korespondensi: syahrial_ayub@unram.ac.id
}

\begin{tabular}{|c|c|}
\hline nfo & \\
\hline $\begin{array}{l}\text { Article History } \\
\text { Received: } 08 \text { Nov } \\
\text { Revised: } 22 \text { Dec } \\
\text { Published: } 30 \text { De }\end{array}$ & \multirow{2}{*}{$\begin{array}{l}\text { Education on Health Protocols in Running the New Normal in Schools } \\
\text { Through Covid-19 Disaster Mitigation Literacy Education. This study aims to } \\
\text { see the effectiveness of COVID-19 disaster mitigation literacy education on } \\
\text { students' knowledge about the spread of the COVID-19 virus, the use of masks, } \\
\text { washing hands and maintaining a distance known as health protocols. This } \\
\text { study also revealed the response of students to literacy education for the } \\
\text { COVID-19 disaster in schools. The research was carried out in class X MIPA } 1 \\
\text { SMAN } 2 \text { Mataram with Define, Design, Develop, and Desseminate (4D) } \\
\text { designs. The results of the study found that literacy education for COVID-19 } \\
\text { disaster mitigation was effective in increasing students' knowledge about the } \\
\text { spread of the COVID-19 virus and the application of health protocols in } \\
\text { schools in the normal era of life. Students also gave a positive response to the } \\
\text { COVID-19 disaster mitigation literacy education in schools. }\end{array}$} \\
\hline $\begin{array}{l}\text { Ke } \\
\text { Pro } \\
\text { hec } \\
\text { lite } \\
19\end{array}$ & \\
\hline In & 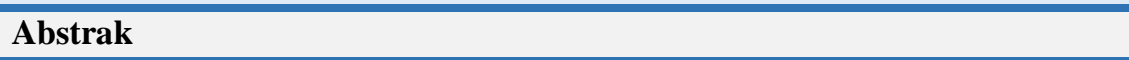 \\
\hline $\begin{array}{l}\text { Sejarah Artike } \\
\text { Diterima: } 08 \text { De } \\
\text { Direvisi: } 22 \text { Des } \\
\text { Dipublikasi: } 30\end{array}$ & \multirow{2}{*}{$\begin{array}{l}\text { Penelitian ini bertujuan melihat efektifitas pendidikan literasi mitigasi bencana } \\
\text { covid19 terhadap pengetahuan peserta didik tentang penyebaran virus covid19, } \\
\text { penggunaan masker, mencuci tangan dan menjaga jarak yang dikenal dengan } \\
\text { protokol kesehatan. Penelitian ini juga mengungkapkan respon peserta didik } \\
\text { terhadap pendidikan literasi bencana covid19 di sekolah. Penelitian } \\
\text { dilaksanakan di kelas X MIPA } 1 \text { SMAN } 2 \text { Mataram dengan desain Define, } \\
\text { Design, Develop, dan Desseminate (4D). Hasil Penelitian mendapatkan } \\
\text { pendidikan literasi mitigasi bencana covid19 efektif dalam meningkatkan } \\
\text { pengetahuan peserta didik tentang penyebaran virus covid19 dan penerapan } \\
\text { protokol kesehatan di sekolah era kehidupan normal. Peserta didik juga } \\
\text { memberikan respon positif terhadap pendidikan literasi mitigasi bencana } \\
\text { covid19 di sekolah. }\end{array}$} \\
\hline $\begin{array}{l}\text { Kata kun } \\
\text { Edukasi p } \\
\text { kesehatan } \\
\text { literasi m } \\
\text { Covid19 }\end{array}$ & \\
\hline \\
\hline
\end{tabular}

\section{PENDAHULUAN}

Hasil penelitian awal menemukan Covid-19 memberikan dampak serius pada sektor pendidikan di Indonesia tidak terkecuali provinsi NTB khususnya di kota Mataram. Berikut ada beberapa dampak pandemi Covid-19 dalam bidang pendidikan di Kota Mataram. Penyebaran virus Corona yang meningkat, membuat pemerintah kota Mataram cepat ambil tindakan, salah satunya menutup sekolah selama dua pekan. Langkah ini diambil pemerintah provinsi demi mencegah penyebaran virus Corona pada peserta didik di sekolah (Samudera, W. 2020). Setiawan, AR (2020) menemukan lembar kerja literasi saintifik untuk 
pembelajaran jarak jauh tentang Covid-19 dapat diterapkan dalam pembelajaran. Pendidikan mitigasi bencana sangat diperlukan oleh peserta didik untuk meningkatkan kesiapsiagaan dan kesadaran bencana pada mereka. Berdasarkan hasil penelitian-penelitian ini dapat digambarkan bahwa bencana non alam Covid-19 berdampak serius terhadap berbagai sektor kehidupan, salah satu sektor yang sangat terdampak adalah pendidikan. Pendidikan mitigasi bencana sangat penting untuk meminimalisir dampak negatif dari bencana non alam Covid19. Pendidikan literasi mitigasi bencana Covid-19 adalah salah satu cara yang dapat dilakukan. Pendidikan literasi secara umum dapat diartikan sebagai kemampuan individu mengolah dan memahami informasi saat membaca atau menulis. Literasi lebih dari sekedar kemampuan baca tulis. Literasi tidak terlepas dari ketrampilan bahasa yaitu pengetahuan bahasa tulis dan lisan yang memerlukan serangkaian kemampuan kognitif, pengetahuan tentang genre dan kultural (Adib, R., S. 2020). Literasi tidak terpisahkan dari dunia pendidikan. Literasi menjadi sarana peserta didik dalam mengenal, memahami, dan menerapkan ilmu yang didapatkannya di bangku sekolah. Literasi juga terkait dalam kehidupan peserta didik, baik di rumah amupun di lingkungan sekitarnya untuk menumbuhkan budi pekerti mulia. Bencana adalah peristiwa atau rangkaian peristiwa yang mengancam atau mengganggu kehidupan dan penghidupan masyarakat yang disebabkan, baik oleh faktor alam dan atau faktor non alam maupun faktor manusia sehingga mengakibatkan timbulnya korban jiwa manusia, kerusakan lingkungan, kerugian harta benda, dan dampak psikologis. Mengurangi dampak bencana diperlukan mitigasi bencana yang merupakan serangkaian upaya untuk mengurangi resiko bencana, baik melalui pembangunan fisik maupun penyadaran dan peningkatan kemampuan menghadapi bencana (Beatrix, $\mathrm{H}$. 2020). Kemampuan Literasi merupakan dasar yang harus dimiliki oleh peserta didik dalam menghadapi era global untuk dapat memenuhi kebutuhan hidup dalam berbagai situasi. Literasi bencana mitigasi bencana merupakan pengetahuan, sikap, dan ketrampilan seseorang tentang upaya dalam pengurangan risiko bencana. kerangka konseptual literasi pencegahan bencana dan dimensi literasi bencana terdiri dari dimensi pengetahuan pengurangan, dimensi sikap pengurangan bencana, dimensi Ketrampilan pencegahan bencana (Calvina, 2020). Literasi mitigasi bencana Covid-19 merupakan kemampuan untuk memahami mitigasi bencana Covid-19, mengkomunikasikan mitigasi bencana Covid-19, serta menerapkan kemampuan mitigasi bencana Covid-19 untuk memecahkan pandemi Covid-19 saat ini (Zahara et al., 2021). Untuk meningkatkan kemampuan literasi mitigasi bencana Covid-19 disamping memerlukan motivasi peserta didik, guru juga perlu mempertimbangkan strategi pembelajaran yang sesuai dengan kondisi dan potensi peserta didik yang mana pada proses pembelajarannya menitik beratkan pada pemberian pengalaman langsung dan pengaplikasian hakikat mitigasi bencana Covid-19, terlebih pada saat ini pembelajaran banyak dilakukan dari rumah sehingga perlu inovasi dalam pelaksanaannya. Konsep literasi dan mitigasi bencana diintegrasikan melalui model pembelajaran student oriented akan menghasilkan tingkah laku, kebiasaan dan kesadaran bencana. Saat ini yang sangat mendesak adalah bagaimana peserta didik memiliki tingkah laku, kebiasaan dan kesadaran bencana Covid-19. Fatia (2020) pelaksanaan program Balai Edukasi Corona selama 14 hari terbukti cukup efektif dilaksanakan untuk mempengaruhi perilaku dan meningkatkan pengetahuan partisipan dalam upaya pencegahan penyebaran Covid-19. Penelitian ini menyimpulkan perilaku dapat dipengaruhi dengan pemberian edukasi atau pendidikan. Model pembelajaran student oriented adalah pembelajaran yang menjadikan peserta didik sebagai pelaku kegiatan (Tim SEQIP, 2010). Proses pembelajaran didesain untuk peserta didik yang menemukan permasalahan, mengajukan hipotesis, melakukan kegiatan untuk menjawab permasalahan yang ditemukan, menyimpulkan, mengaplikasikan dan mengkomunikasikan konsep yang didapatkan. Cara ini diharapkan mampu mengubah perilaku, kebiasaan dan kesadaran peserta didik terhadap segala permasalahan dan perubahan yang diharapkan. Perilaku peserta didik dalam menerapkan secara disiplin protokol kesehatan di era kehidupan baru menjadi sangat 
penting guna memutus mata rantai penularan covid-19. Saat era kehidupan baru secara bertahap sekolah sekolah akan kembali dibuka untuk pembelajaran tatap muka. Ini akan memungkinkan interaksi sosial diantara peserta didik, guru dan masyarakat sekolah akan terjadi. Sementara pandemi covid19 belum usai dan penularan masih terjadi. Kondisi ini tentu menimbulkan kekuatiran bagi orang tua dan bahkan peserta didik itu sendiri, olehkarena itu perilaku peserta didik terhadap penerapan protokol kesehatan di sekolah harus sesuai dengan standar kementerian kesehatan. Pembentukan perilaku dibagi 3 cara sesuai keadaan yang diharapkan, yaitu pertama, cara pembentukan perilaku dengan kebiasaan. Cara membiasakan diri untuk berperilaku seperti yang diharapkan, akhirnya akan terbentuklah perilaku tersebut. Kedua, pembentukan perilaku dengan pengertian. Cara ini, berdasarkan atas teori belajar kognitif, yaitu belajar dengan pengertian.Ketiga, pembentukan perilaku dengan menggunakan model atau contoh. Pendapat ini memberikan isyarat bahwa perilaku akan terbentuk dari kebiasaan, pengertian dan model. Kebiasaan diwujudkan dalam bentuk disiplin melaksanakan protokok kesehatan Covid-19. Laxmi (2017) mengatakan praktek yang dilaksanakan berulang akan menjadi perilaku. Perilaku juga akan munculdari kebiasaan dan contoh yang diberikan. Kebiasaan dan contoh ini, sesuai dengan perkembangan peserta didik sekolah (Ibrahim, 2000). Pendapat-pendapat ini, mengindikasikan bahwa perilaku dapat diubah melalui pendidikan. Penelitian ini membahas tentang edukasi protokol kesehatan di sekolah melalui pendidikan literasi mitigasi bencana covid-19.

\section{METODE}

Penelitian ini menggunakan jenis research and development dengan desain penelitian 4D model yaitu Define, Design, Develop, dan Desseminate (Borg and Gall, 1983). Pada tahap Define dilakukan analisis pengetahuan bencana Covid-19 (PBCov19) yang akan dikembangkan, analisis protokol kesehatan Covid-19 (PKCov19), analisis dampak resiko dan upaya mengurangi (DRCov19), analisis kesiapsiagaan Covid19 (KCov19), dan analisis prosedur pada korban dan keluarga Covid-19 (APCov19). Tahap Design dilakukan perancangan perangkat pembelajaran pendidikan literasi mitigasi bencana non alam Covid19. Pada tahap Develop dilakukan pembuatan produk, validasi ahli produk, revisi produk, ujicoba alat evaluasi mitigasi bencana non alam Covid19, sedangkan pada tahap Desseminate, pada tahap ini dilakukan penyebarluasan produk dengan melaksanakan pendidikan mitigasi bencana non alam Covid19 pada peserta didik di sekolah. Metode yang digunakan ini, adalah penelitian dan pengembangan (research \& development). Metode penelitian dan pengembangan adalah penelitian yang digunakan untuk menghasilkan produk tertentu dan menguji keefektifan produk tersebut (Sugiyono, 2011). Data penelitian dikumpulkan melalui tes, observasi, wawancara dan dokumentasi, dengan instrumen penelitian berupa lembar soal literasi mitigasi bencana non alam Covid19, lembar observasi kegiatan pembelajaran literasi mitigasi bencana non alam Covid-19 bagi peserta didik, angket validasi perangkat pembelajaran, angket respon peserta didik dan alat perekam dokumen penelitian. Penelitian ini dilakukan di sekolah menengah atas 2 di Mataram. Berikut adalah diagram alir penelitiannya :

\begin{tabular}{|l|l|l|}
\hline Mulai $\rightarrow \begin{array}{l}\text { Observasi dan } \\
\text { pengumpulan } \\
\text { data awal }\end{array}$ & $\rightarrow \begin{array}{l}\text { Pengumpulan data awal } \\
\text { Pengumpulan hasil penelitian awal }\end{array}$
\end{tabular}




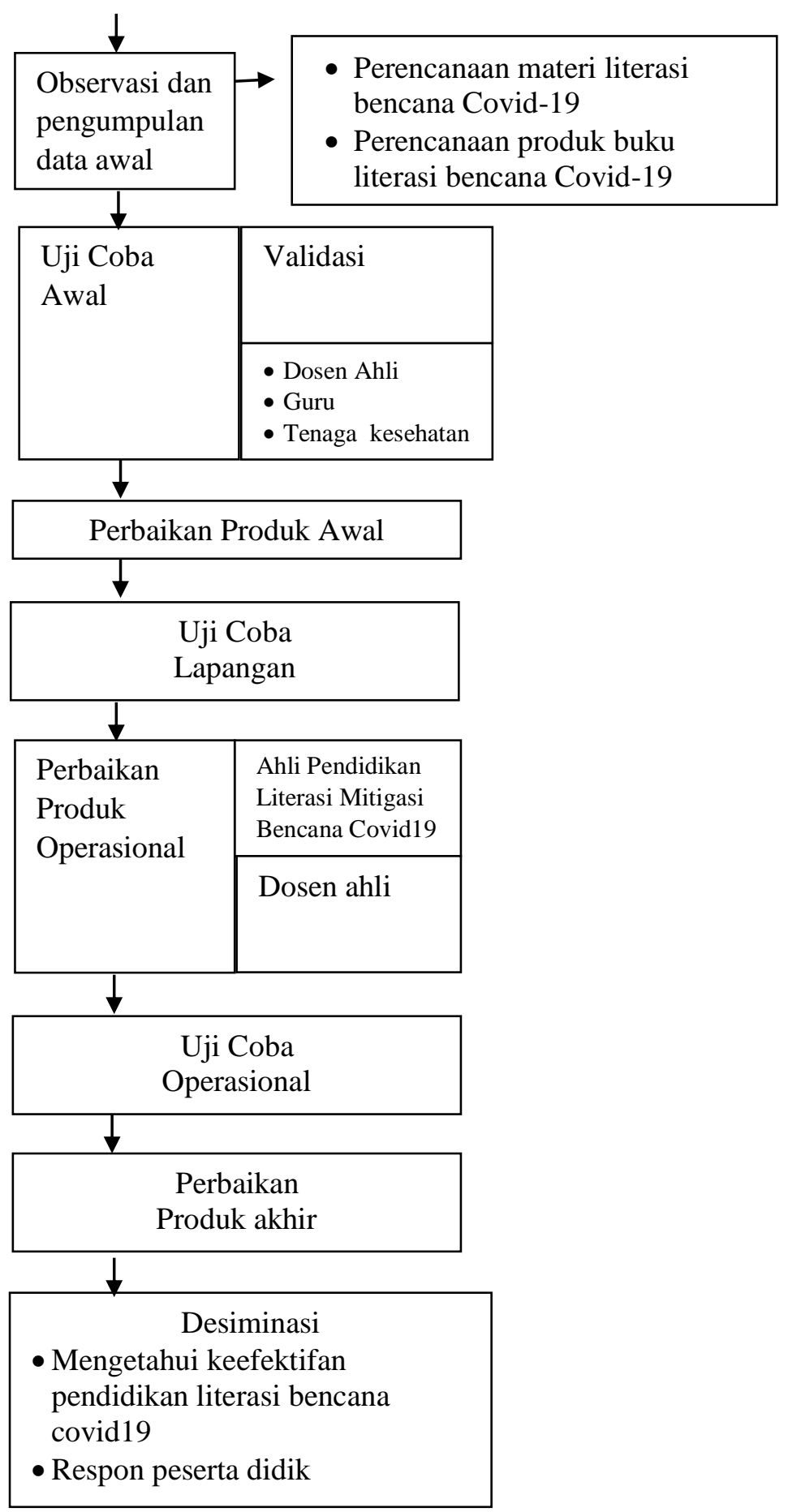

Gambar 1 : Tahapan Penelitian

Tes awal dilakukan sebelum kegiatan pembelajaran literasi bencana Covid19, sedangkan tes akhir diberikan setelah pembelajaran berakhir. Menurut Hake, R. (1999), nilai Gain dihitung dengan persamaan:

$$
<g>=\frac{s_{\text {post }} S_{\text {pre }}}{s_{\text {maks }} S_{\text {pre }}}
$$

Dimana, $<g>$ adalah skor Gain, $S_{\text {post }}$ adalah skor tes akhir $S_{\text {pre }}$ adalah skor tes awal dan $S_{\text {maks }}$ adalah akor maksimal.

\section{Tabel 1: Kriteria Skor Gain}




\begin{tabular}{cc}
\hline Klasifikasi Skor Gain & Kategori \\
\hline $0,7<\langle g\rangle \leq 1$ & Tinggi \\
\hline $0,3<\langle g\rangle \leq 0,7$ & Sedang \\
\hline$\langle g\rangle \leq 0,3$ & Rendah \\
\hline
\end{tabular}

Nilai rata-rata validator ditentukan dengan menggunakan persamaan NA (Ratumanan, 2011)

$$
N A=\frac{V_{1}+V_{2}+V_{3}+V_{4}}{4}
$$

Nilai NA akan dikonsultasikan pada tabel 2 berikut ini :

Tabel 2 : Kriteria Penilaian Validitas

\begin{tabular}{lll}
\hline \multicolumn{1}{c}{ Rata-Rata } & \multicolumn{1}{c}{ Kategori } & \multicolumn{1}{c}{ Keputusan } \\
\hline $\mathbf{1 , 0 0}-\mathbf{1 , 7 5}$ & Tidak Valid & Revisi Total \\
\hline $\mathbf{1 , 7 6}-\mathbf{2 , 5 0}$ & Cukup Valid & Revisi \\
\hline $\mathbf{2 , 5 1}-\mathbf{3 , 2 5}$ & Valid & Revisi sesuai Saran \\
\hline $\mathbf{3 , 2 6}-\mathbf{4 , 0 0}$ & Sangat Valid & Tidak perlu Revisi \\
\hline
\end{tabular}

Analisis reliabilitas perangkat pembelajaran literasi bencana Covid19 menggunakan metode Borich yang dikenal dengan Percentage Agreement (PA). PA adalah prosentase kesepakatan antara penilai pertama dengan kedua. PA dirumuskan :

$$
P A=\left(1-\frac{A-B}{A+B}\right) 100 \%
$$

A merupakan skor penilai yang lebih besar dan B skor yang lebih kecil. Instrumen akan dikatakan reliabel jika PA $\geq 75 \%$ (Borich, 1994). Analisis dilanjutkan dengan melakukan uji kepraktisan bahan literasi mitigasi bencana Covid19 dan keefektifannya, sehingga penelitian ini dapat diyakini kebenarannya secara statistik dan kehidupan nyata. Indikator capaiannya dapat dilihat dari peningkatan kesadaran bencana Covid19 yang diimplementasikan dalam bentuk perilaku dan kebiasaan kehidupan baru yang disiplin dan kontinu.

\section{HASIL DAN PEMBAHASAN}

\section{Hasil Penelitian}

\section{Validasi Modul}

Langkah-langkah yang dilakukan untuk mendapatkan modul yang baik, sesuai, jelas dan mudah dipahami oleh peserta didik adalah: (a) langkah pertama, dilakukan validasi isi modul yaitu modul awal yang telah dikembangkan oleh tim kemudian didiskusikan dalam kelompok ahli yang terdiri dari dosen, guru dan tenaga kesehatan serta ahli literasi. Pada langkah pertama ini yang dicermati adalah validitas isi modul, gaya bahasa dan kata-kata yang digunakan dalam modul. Isi modul dibandingkan dengan konsep teoritik yang mendasari, sedangkan penggunaan gaya bahasa dan kata-kata di dalam modul diarahkan kepada yang sederhana dan mudah dipahami. Langkah kedua melakukan uji validitas keterbacaan di lapangan. Ujicoba pertama di lapangan dilakukan pada kelompok kecil, yaitu pada 5 peserta didik untuk setiap sub modul, Langkah ini bertujuan agar apabila modul yang dikembangkan belum memadai, maka dapat dilakukan revisi yang diperlukan, baru setelah itu dilakukan ujicoba pada kelompok yang lebih besar. Hasilnya skor tesnya 65\%, berarti modul mudah dipahami. Kriteria persentase skor tes di atas $60 \%$, berarti modul mudah dipahami atau independen, persentase skor tes antara 41-60\%, maka modul tersebut termasuk kategori sedang atau instruksional, persentase skor tes kurang dari $40 \%$, maka modul tersebut termasuk kategori kurang atau sulit dipahami atau gagal. 


\section{Validasi RPP}

Validasi rencana pelaksanaan pembelajaran (rpp) dilakukan dengan membuat kuesioner validasi rpp untuk validator. Kuesioner validasi rpp ini dikembangkan dari indikator rpp yang baik. Hasil validasi rpp mitigasi covid19 yang terdiri dari rpp penyebaran virus covid19, penggunaan masker, mencuci tangan dan menjaga jarak diperoleh rata-rata dari validator satu 3,12, validator dua 3,18 dan validator tiga 3,24 dengan rata-rata skor 3,18, bila dikonsultasikan dengan kriteria tabel 2 maka kategori validasi rpp adalah valid. Aspek yang dinilai adalah aspek pengamatan pembelajaran di kelas dengan pendidikan literasi bencana covid19 berbasis peserta didik.

\section{Validasi LKPD}

LKPD literasi mitigasi bencana covid19 dikembangkan untuk menuntun peserta didik dalam menemukan konsep yang akan ditemukan dalam pembelajaran. Berikut adalah hasil analisis validasi LKPD literasi bencana covid19 berbasis student oriented.

Tabel 3 : Hasil Analisis Validitas LKPD Literasi Mitigasi Covid19

\begin{tabular}{|c|c|c|c|c|c|c|}
\hline \multirow[t]{2}{*}{ No } & \multirow[t]{2}{*}{ Aspek yang dinilai } & \multicolumn{3}{|c|}{ Skor dari Validator } & \multirow{2}{*}{$\begin{array}{l}\text { Rata- } \\
\text { Rata } \\
\text { skor }\end{array}$} & \multirow[t]{2}{*}{ Kategori } \\
\hline & & I & II & III & & \\
\hline 1 & tampilan LKPD menarik & 3 & 3 & 4 & 3.33 & sangat valid \\
\hline 2 & $\begin{array}{l}\text { gambar yang digunakan jelas dan } \\
\text { sesuai tujuan }\end{array}$ & 4 & 3 & 3 & 3.33 & sangat valid \\
\hline 3 & petunjuk di LKPD mudah dipahami & 4 & 4 & 4 & 4.00 & sangat valid \\
\hline 4 & penggunaan bahasa baku dan jelas & 3 & 3 & 2 & 2.67 & valid \\
\hline 5 & langkah-langkah di LKPD sesuai & 4 & 4 & 4 & 4.00 & sangat valid \\
\hline 6 & $\begin{array}{l}\text { dengan literasi mitigasi covid19 } \\
\text { soal di LKPD mengacu kepada } \\
\text { tujuan } \\
\text { materi ajar dan proses literasi }\end{array}$ & 4 & 3 & 3 & 3.33 & valid \\
\hline & Rata-Rata total & & & & 3.44 & sangat valid \\
\hline
\end{tabular}

4. Validasi tes

Tes pemahaman konsep penyebaran virus covid19, penggunaan masker, mencuci tangan dan menjaga jarak dari pendidikan literasi mitigasi bencana covid19 divalidasi oleh 3 orang validator yang masing-masing berasal dari dosen, guru dan tenaga kesehatan. Hasil validasi tes literasi mitigasi bencana covid19 adalah:

Tabel 4 : Hasil Analisis Validitas Tes Literasi Mitigasi Covid19

\begin{tabular}{|c|c|c|c|c|c|c|}
\hline \multirow[t]{2}{*}{ No } & \multirow[t]{2}{*}{ Aspek yang dinilai } & \multicolumn{3}{|c|}{ Skor dari Validator } & \multirow{2}{*}{$\begin{array}{l}\text { Rata- } \\
\text { Rata } \\
\text { skor }\end{array}$} & \multirow[t]{2}{*}{ Kategori } \\
\hline & & I & II & III & & \\
\hline 1 & Identitas tes ditulis dengan jelas & 3 & 3 & 3 & 3.00 & valid \\
\hline 2 & $\begin{array}{l}\text { petunjuk mengerjakan mudah } \\
\text { Dipahami }\end{array}$ & 3 & 3 & 3 & 3.00 & valid \\
\hline 3 & $\begin{array}{l}\text { indikator soal sesuai dengan } \\
\text { kompetensi dasar }\end{array}$ & 3 & 4 & 4 & 3.67 & sangat valid \\
\hline 4 & $\begin{array}{l}\text { soal mengacu pada handout dan } \\
\text { materi ajar }\end{array}$ & 3 & 3 & 4 & 3.33 & sangat valid \\
\hline 5 & $\begin{array}{l}\text { soal mengacu pada literasi mitigasi } \\
\text { bencana covid } 19\end{array}$ & 4 & 3 & 3 & 3.33 & sangat valid \\
\hline
\end{tabular}




\begin{tabular}{lllllll}
6 & soal menggunakan kata kata baku & 3 & 3 & 3 & 3.00 & valid \\
7 & penggunaan bahasa mudah dipahami & 4 & 3 & 3 & 3.33 & sangat valid \\
\hline Total rata-rata & & & & $\mathbf{3 . 2 4}$ & valid \\
\hline
\end{tabular}

5. Reliabilitas Produk

Produk penelitian yang berupa modul, rencana pelaksanaan pembelajaran (rpp), lembar kegiatan peserta didik (LKPD) dan instrumen tes literasi mitigasi bencana covid19 di analisis reliabilitasnya. Reliabilitas produk menggunakan metode Borich yaitu Percentage Agreement (PA) yaitu prosentase kesepakatan antara penilai yang merupakan prosentase kesesuaian nilai antara penilai. Hasil analisis reliabilitas produk dapat dilihat pada tabel 5 berikut ini:

Tabel 5 : Analisis Reliabilitas Produk

\begin{tabular}{lllllll}
\hline \multirow{2}{*}{ No } & \multicolumn{1}{c}{ Produk } & \multicolumn{2}{c}{ Nilai PA Validator } & $\begin{array}{c}\text { Rata- } \\
\text { Rata }\end{array}$ & Kategori \\
& & V12 & V13 & V23 & PA & \\
\hline 1 & $\begin{array}{l}\text { Modul Literasi Mitigasi } \\
\text { bencana covid19 }\end{array}$ & $85 \%$ & $90 \%$ & $83 \%$ & 0.86 & Reliabel \\
2 & $\begin{array}{l}\text { Rencana Pelaksanaan } \\
\text { Pembelajaran (RPP) } \\
\text { literasi bencana Covid19 }\end{array}$ & $83 \%$ & $85 \%$ & $85 \%$ & 0.84 & Reliabel \\
$\begin{array}{l}\text { Lembar Kegiatan Peserta } \\
\text { didik (LKPD) literasi mitigasi } \\
\text { bencana covid19 }\end{array}$ & $85 \%$ & $83 \%$ & $95 \%$ & 0.88 & Reliabel \\
4 & $\begin{array}{l}\text { Instrumen tes literasi mitigasi } \\
\text { bencana covid19 }\end{array}$ & $80 \%$ & $85 \%$ & $83 \%$ & 0.83 & Reliabel \\
\hline & Total rata-rata & & & & Reliabel \\
\hline
\end{tabular}

6. Hasil Tes Awal dan Tes Akhir

Implementasi pendidikan literasi bencana covid19 di SMA Negeri 2 Mataram dilakukan 4 pertemuan dengan masing masing tentang konsep penyebaran virus covid19 (PVC19), penggunaan masker (PMC19), mencuci tangan (MTC19) dan menjaga jarak (MJC19). Sebelum implementasi dilaksanakan peserta didik di beri tes awal dan setelah 4 pertemuan kembali mereka diberikan tes akhir. Hasil tes awal dan tes akhir seperti pada gambar 2 berikut ini: 


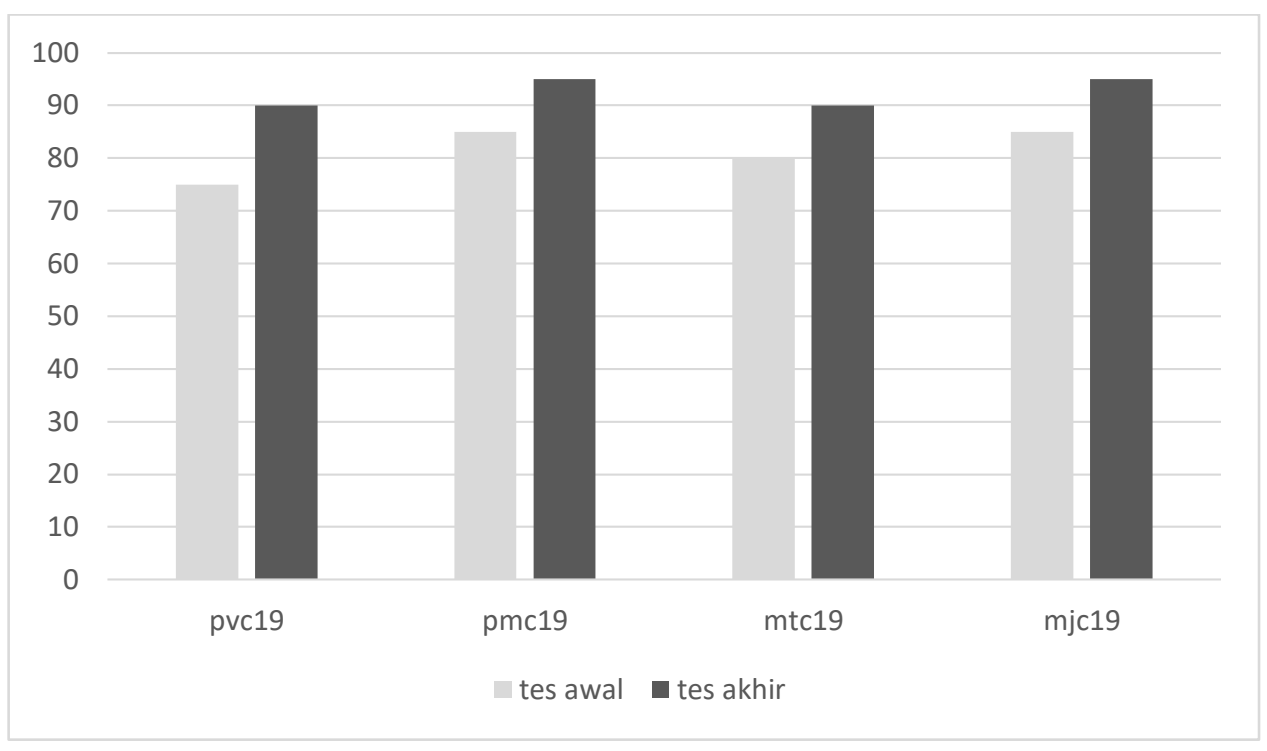

Gambar 2 : Hasil Tes Awal dan Tes Akhir Pendidikan Literasi Bencana Covid19

7. N-Gain Peserta Didik terhadap Pengetahuan Mitigasi Bencana Covid19

Berdasarkan tes awal dan tes akhir yang diperoleh oleh masing-masing peserta didik dapat N-Gain Score dari mereka, yaitu terlihat pada tabel 6 berikut ini:

Tabel 6 : N-Gain Score Peserta Didik

\begin{tabular}{|c|c|c|c|}
\hline pretest & postest & $\mathbf{N}$-Gain & kriteria \\
\hline 80 & 90 & $\mathbf{0 . 5 0}$ & sedang \\
\hline 75 & 90 & $\mathbf{0 . 6 0}$ & sedang \\
\hline 75 & 90 & $\mathbf{0 . 6 0}$ & sedang \\
\hline 85 & 95 & $\mathbf{0 . 6 7}$ & sedang \\
\hline 85 & 95 & $\mathbf{0 . 6 7}$ & sedang \\
\hline 80 & 95 & $\mathbf{0 . 7 5}$ & tinggi \\
\hline 80 & 95 & $\mathbf{0 . 7 5}$ & tinggi \\
\hline 75 & 90 & $\mathbf{0 . 6 0}$ & sedang \\
\hline 75 & 90 & $\mathbf{0 . 6 0}$ & sedang \\
\hline 80 & 90 & $\mathbf{0 . 5 0}$ & sedang \\
\hline 80 & 90 & $\mathbf{0 . 5 0}$ & sedang \\
\hline 85 & 95 & $\mathbf{0 . 6 7}$ & sedang \\
\hline 85 & 90 & $\mathbf{0 . 3 3}$ & sedang \\
\hline 75 & 90 & $\mathbf{0 . 6 0}$ & sedang \\
\hline 80 & 90 & $\mathbf{0 . 5 0}$ & sedang \\
\hline 80 & 95 & $\mathbf{0 . 7 5}$ & sedang \\
\hline $\mathbf{7 9 . 6 9}$ & $\mathbf{9 1 . 8 8}$ & $\mathbf{0 . 6 0}$ & sedang \\
\hline
\end{tabular}

$\mathrm{N}-$ Gain (normalized gain) digunakan untuk mengukur peningkatan hasil belajar kognitif peserta didik melalui pendidikan literasi mitigasi bencana covid19 tentang penyebaran virus covid19 (PVC19), penggunaan masker (PMC19), mencuci tangan (MTC19) dan menjaga jarak (MJC19).

8. Respon Peserta Didik terhadap Penerapan Pendidikan Literasi Mitigasi Bencana Covid19 
Respon peserta didik terhadap penerapan pendidikan literasi mitigasi bencana covid19 di SMA Negeri 2 kelas X MIPA 1 adalah:

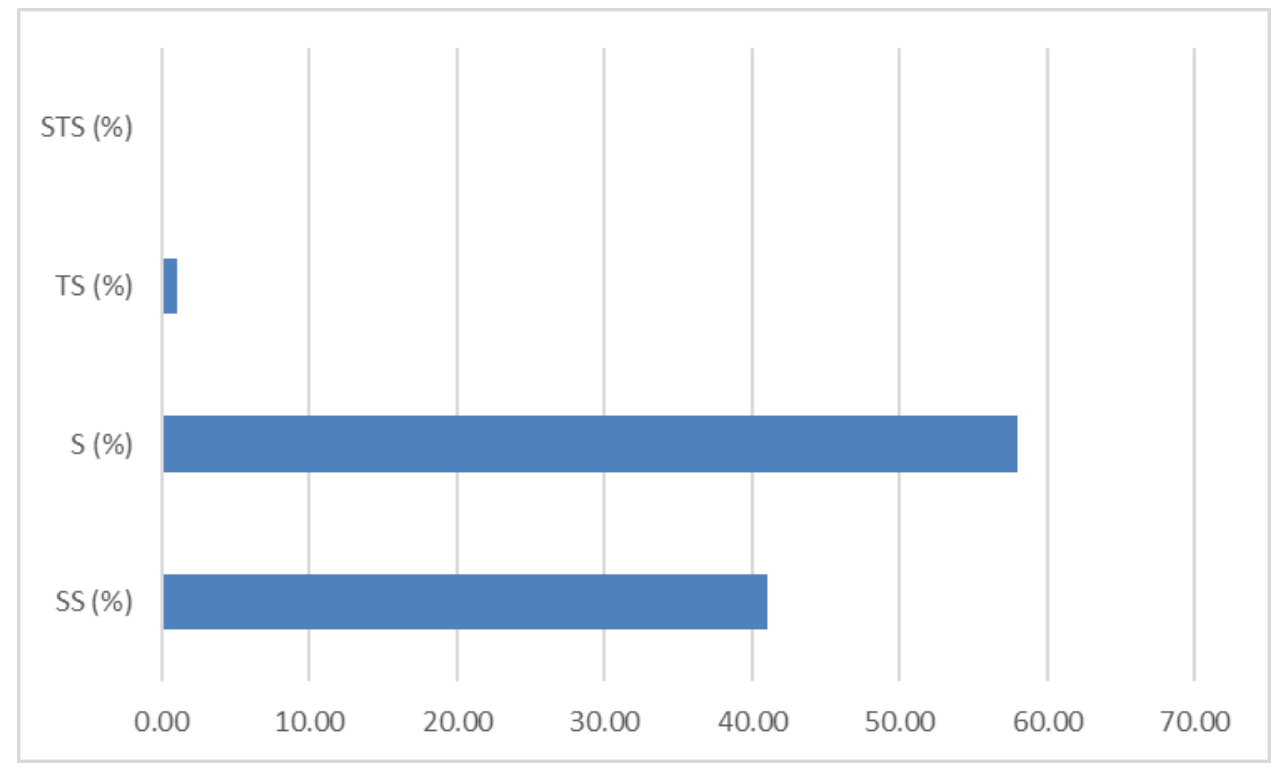

Gambar 3 : Rata-Rata Respon Peserta Didik terhadap Penerapan Pendidikan Literasi Bencana Covid19 di Sekolah

9. Foto-Foto Kegiatan Penelitian
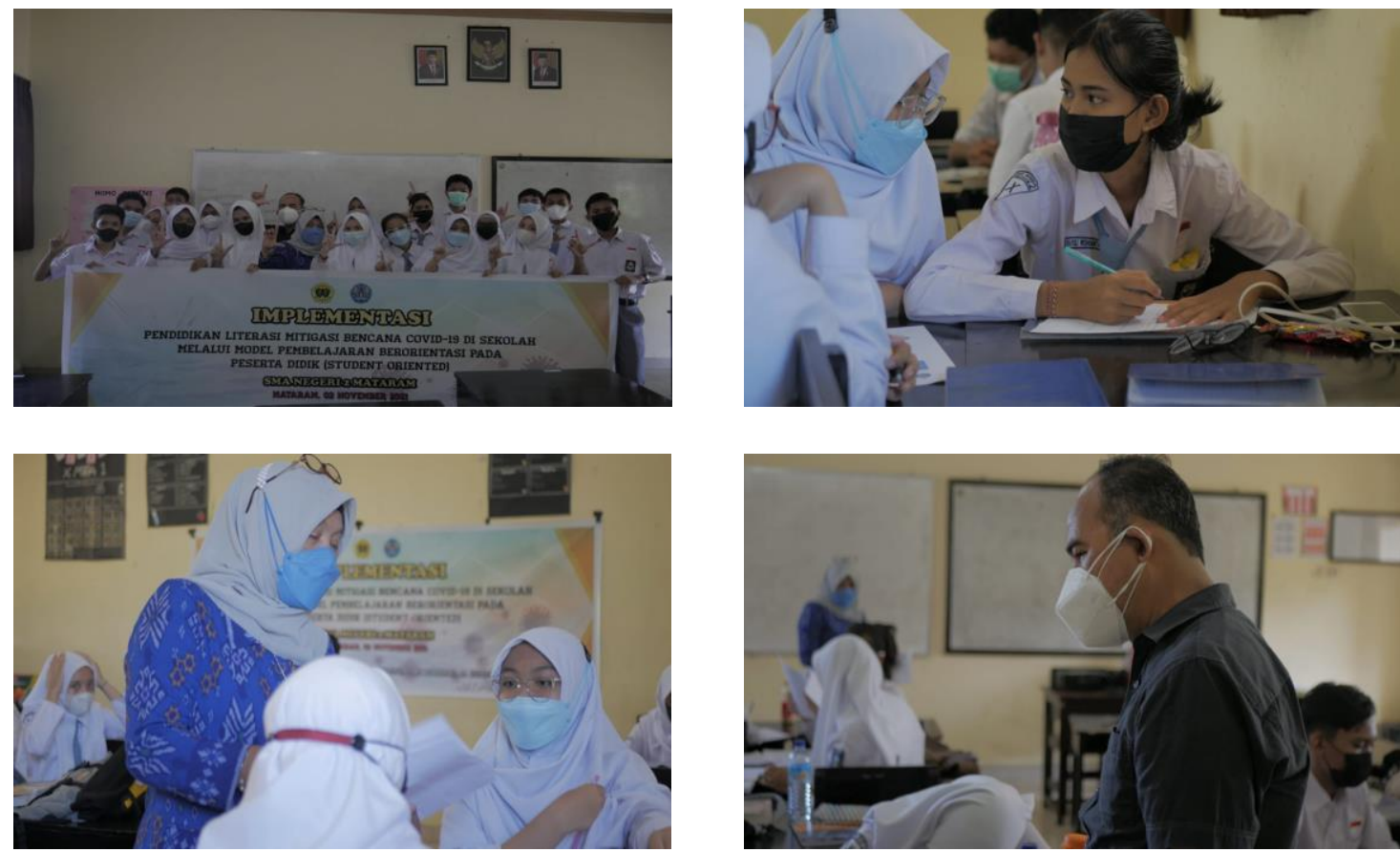

Gambar 4 : Foto-Foto Kegiatan Penelitian di kelas X MIPA 1 SMAN 2 Mataram

\section{Pembahasan}

Produk penelitian berupa modul, rpp, lkpd, dan instrumen tes literasi mitigasi bencana covid19 efektif dalam meningkatkan pengetahuan penyebaran virus covid19 (PVC19), penggunaan masker (PMC19), mencuci tangan (MTC19) dan menjaga jarak (MJC19) dengan kategori sedang. Kategori sedang dimungkinkan tim belum optimal dalam menggunakan 
media dalam penerapan pendidikan literasi mitigasi bencana covid19. Seperti media video edukasi tentang penerapan protokol kesehatan untuk masyarakat. Ainur Rosidah (2020), mengatakan Video edukasi ini diunggah di Youtube dan Facebook, yaitu media sosial yang banyak digunakan oleh berbagai kalangan. Hal ini dimaksudkan agar dapat memberikan pengaruh positif dalam rangka meningkatkan kesadaran masyarakat untuk mendukung upaya pemerintah menghadapi Covid-19. Tujuan penyebarluasan video ini untuk meningkatkan upaya pencegahan dan pengendalikan covid-19 di tempat dan fasilitas umum. Sehingga dengan adanya informasi yang diberikan, masyarakat lebih memahami dan meningkatkan pengetahuan mengenai protokol kesehatan dalam rangka memutus rantai penyebaran virus covid-19. Poster juga efektif dalam memberikan edukasi protokol kesehatan kepada masyarakat. Penggunaan poster meningkatkan minat baca masyarakat sehingga efektif dalam meningkatkan kesadaran masyarakat dalam menerapkan protokol kesehatan. Solusi dan upaya penerapan protokol Kesehatan di era new normal adalah dengan mematuhi dan menerapkan protokol kesehatan minimal yang harus di patuhi di era new normal yaitu $3 \mathrm{M}$ (Menggunakan Masker, selalu Menjaga Jarak, dan Mencuci Tangan) dapat meningkatkan pencegahan persebaran virus covid19 sekaligus dapat meningkatkan kebersihan tubuh untuk menghindari berbagai virus yang dapat menyerang tubuh. Semua segmen masyarakat harus bisa bergotong royong dalam kedisplinan penerapan protokol kesehatan (Winarso Sugeng, 2020). Perilaku disiplin dalam menerapkan protokol kesehatan tidak diperoleh dengan mudah karena membutuhkan proses. Proses mendapatkan perilaku ini melalui pendidikan literasi mitigasi bencana covid19 adalah menerapkannya dalam pembelajaran di kelas. Tahapan pembelajaran literasi mitigasi bencana covid19 ini dimulai dari tahapan mengamati, berpendapat, membaca jurnal, mencatat, dan mempresentasikannya di depan temantemannya. Presentasi dimaksudkan supaya peserta didik mampu mengimbaskan pengetahuan dan keterampilan yang dimiliki kepada teman terdekatnya, keluarga dan bahkan masyarakat di sekitarnya. Bila tahapan tahapan literasi dibandingkan dengan tahapan pokok pembelajaran sangat sesuai. Mulya (2020), tahapan pokok pembelajaran ada 3 yaitu kegiatan awal, kegiatan inti dan kegiatan akhir. Syahrial A. (2020), setiap kegiatan mempunyai tujuan masingmasing, kegiatan awal bertujuan memotivasi peserta didik sebelum pembelajaran yang sebenarnya dilaksanakan. Terdapat banyak alternatif kegiatan yang dapat dipilih guru untuk memotivasi peserta didik. Tahapan mengamati memberikan kebebasan kepada guru untuk menentukan kegiatannya, karena dibalik kata mengamati tersirat banyak alternatif kegiatan. Harapannya dengan kegiatan mengamati muncul rasa ingin tahu dari peserta didik yang diimplimentasikan dengan pertanyaan. Pertanyaan yang muncul merupakan rumusan masalah pembelajarannya. Permasalahan mitigasi bencana covid19 yang muncul tidak boleh langsung dijawab oleh guru. Peserta didik diperkenankan untuk berpendapat yang dalam keterampilan proses sains dinamakan dugaan sementara (hipotesa). Kegiatan selanjutnya adalah literasi, guru memberikan jurnal bacaan kepada peserta didik berkenaan dengan permasalahan yang muncul. Ini adalah kegiatan inti pada pendidikan literasi mitigasi bencana covid19. Peserta didik kemudian meringkas bacaan dari jurnal yang diberikan guru. Ringkasan itu dicatat di dalam buku catatannya. Setelah diskusi di kelompoknya peserta didik dapat mempresentasikan hasil mereka didepan teman-temannya. Tahapan ini diharapkan mampu menyempurnakan hasil yang mereka dapatkan, sehingga konsep yang tertanam benar benar mantap. Tahapan berikutnya adalah peserta didik diharapkan mampu mengimbaskan kepada teman dekat, keluarga dan bahkan masyarakat di sekitarnya. Pendidikan literasi mitigasi bencana covid19 berorientasi kepada peserta didik (student oriented). Model pembelajaran student oriented adalah salah satu model yang berorientasi kepada peserta didik. Pusat kegiatan dalam pembelajaran dilakukan oleh peserta didik, guru hanya sebagai fasilitator dan memberikan penjelasan bila merasa diperlukan saja. Diharapkan dalam model pembelajaran ini, peserta didik yang menemukan masalah pembelajaran dan peserta didik juga yang akan menemukan jawaban dari permasalahan itu melalui kegiatan yang mereka lakukan sendiri. 
Harapannya kemampuan peserta didik dalam memecahkan masalah meningkat. Suatu aktifitas yang sering diulang melakukannya akan menjadi kebiasaan. Kebiasaan mandiri inilah yang diinginkan muncul pada peserta didik dalam memecahkan masalah-masalah. Kebiasaan akan menjadi perilaku dalam bertindak, perilaku disiplin dalam menerapkan protokol kesehatan bagi peserta didik diharapkan akan terwujud, sehingga mata rantai penularan covid19 bisa diputus.

\section{KESIMPULAN}

Pendidikan literasi mitigasi bencana covid19 efektif dalam meningkatkan pengetahuan peserta didik tentang penyebaran virus covid19, penggunaan masker, mencuci tangan dan menjaga jarak serta mendapat respon positif dari peserta didik.

\section{SARAN}

Harapan kami, supaya kegiatan pendidikan literasi mitigasi bencana covid19 ini dapat diterapkan pada skala yang lebih luas melibatkan banyak sekolah dari berbagai jenjang pendidikan supaya kesadaran mitigasi bencana covid19 dengan disiplin menerapkan protokol kesehatan dapat menjadi perilaku di kehidupan masyarakat, sehingga mata rantai penularan covid19 bisa diputus.

\section{UCAPAN TERIMA KASIH}

Terima kasih kami ucapkan kepada Universitas Mataram yang telah memfasilitasi dan mendanai kegiatan ini melalui dana PNBP semoga kegiatan ini memberikan manfaat kepada sekolah dan masyarakatr. Terima kasih juga kami ucapkan kepada kepala sekolah, guru dan peserta didik di SMA Negeri 2 Mataram, terutama kelas X MIPA 1 yang telah meluangkan waktunya dan berpartisipasi dalam kegiatan penelitian ini.

\section{DAFTAR PUSTAKA}

Ainur Rosidah, Binti Anisaul Khasanah, Rahmatika Kayis. (2020). Meningkatkan Kesadaran Masyarakat Terhadap Pencegahan Covid-19 melalui Video Edukasi Penerapan Protokol Kesehatan. Jurnal Logista. 4(2), 414-419

Adib, R., S. (2020). Lembar Kegiatan Literasi Saintifik untuk Pembelajaran Jarak Jauh Topik Penyakit Coronavirus 2019 (COVID-19). Edukatif Jurnal Ilmu Pendidikan, 2 (1), 2837.

Borich, G., D., (1994). Obsevation Skill for Effective Teaching. New York: Macmillan Publishing Company.

Beatrix, H. (2020). Pentingnya Penerapan Pendidikan Mitigasi Bencana di Sekolah untuk Mengetahui Kesiapsiagaan Peserta Didik. Jurnal Edukasi Non Formal, 1(2). 94-102.

Borg. W.R dan Gall, M.D. (1983). Educational Reasearch: An Introduction. Longman :New York.

Calvina Izumi Atmajanti, Gavrial Caesarissa Richtiara, Kinanti Khairunnisa I.S. (2020). Edukasi Protokol Kesehatan New Normal dan Pengenalan Dunia Bisnis di Tengah Pandemi Covid-19 melalui Media Sosial. Jurnal Layanan Masyarakat. 4(2), 472-478

Fatia, Z., Henni, K., Upaya Balai Edukasi Corona Berbasis Media Komunikasi dalam Pencegahan Penyebaran Covid-19, Jurnal Abdimas Kesehatan Perintis, Vol.2 No.1, h.17-24, Juli 2020 
Hake, R. (1999). Analyzing Change Gain Score. Unpublished.[online] URL: http://www. physics. indiana. edu/ sdi/AnalyzingChange-Gain. Pdf.

Ibrahim, Muslimin. 2000. Pembelajaran Berdasarkan Masalah. Surabaya: University Press.

Laxmi. (2017). Implementasi Pembelajaran Berbasis Masalah Melalui Lesson Study untuk Meningkatkan Kemampuan Pemecahan Masalah dan Aktivitas Belajar Mahasiswa. Jurnal Kappa, 1(1). 21-30.

Mulya, R. (2020). Pengembangan Perangkat Pembelajaran Model Reasoning and Problem Solving untuk Meningkatkan Kemampuan Pemecahan Masalah Fisika Peserta Didik. S1 Skripsi. Universitas Mataram.

Ratumanan, G., T. \& Laurens, T., (2011). Evaluasi Hasil Belajar pada Tingkat Satuan Pendidikan. Surabaya : UNESA University Press.

Sugiyono. (2011). Metode Penelitian Kuantitaif Kualitatif dan R\&D. Bandung: Alfabeta

Syahrial A., Gusti Afifah, \& I Wayan Gunada. (2020). Pengembangan Model Pembelajaran Student Oriented dalam Meningkatkan Kemampuan Pemecahan Masalah Fisika Peserta Didik. Jurnal Kappa, 4(2). 197-203.

Samudra, W. (2020). Dampak Pandemi Covid19 dalam Bidang Pendidikan di Kota Mataram. Indonesian Journal of Teacher Education, 1 (3). 154-158.

Setiawan, A. (2020). Lembar Kegiatan Siswa untuk Pembelajaran Jarak Jauh Berdasarkan Literasi Saintifik pada Topik Penyakit Coronavirus 2019 (Covid19). Jurnal Pendidikan, 2 (2). 25-37.

Tim SEQIP. (2010). Model Pembelajaran Student Oriented. Jakarta: Depdiknas

Winarso Sugeng, Prastyantoko Kukuh, Prasetya Dhanny. (2020). Penerapan Protokol Kesehatan COVID-19 di Era New Normal Pada Kampung Tangguh Desa Karangdoro, Terminal Jajag, dan RTH Maron Genteng, Kabupaten Banyuwangi. Multidisciplinary Journal. 3(1), 25-33

Zahara, L., Syahidi, K., \& Aryani, B. (2021). Pendampingan dan Edukasi Masyarakat tentang Hidup Sehat di Masa Pandemi Covid-19 di Kelurahan Kelayu Utara , Kec . Selong , Kab. Lombok. 02(2). 